\title{
MORINGA PLANT, Moringa oleifera LAM., AS A SOURCE OF BIOPESTICIDE
}

\author{
Ghada N. El-Masry*, Fatma M. Saleh and Sanaa A. M. Abd El-Mageed \\ Inst. Plant Protection, Cent. Agric. Res., Egypt.
}

\begin{abstract}
Fifty grams of Moringa seeds were ground and then sieved. The solvent methylene chloride was added to the fine powder. The obtained solution was submitted to column chromatography analyzed. Each output was separated and identified by Fourier Transform Infrared spectroscopy (FTIR), ${ }^{13}$ Carbon and Nuclear magnetic resonance spectroscopy. The obtained substances were tested against each of the adult females of the two spotted spider mite Tetrancus urticae (Koch) and the cotton mealybug Phenacoccus solenopsis Tinsley. The efficiency effects of the obtained compounds were evaluated after 24 hours after application. No effect for all the tested compounds was recorded except for Rhamnosyloxy-benzyl isothiocyanate. The results showed that the values of $\mathrm{LC}_{25}, \mathrm{LC}_{50}$ and $\mathrm{LC}_{90}$ were 150, 388 and $2370 \mathrm{ppm}$, respectively after application for the two spotted spider mite $T$. urticae, whereas $\mathrm{LC}_{25}, \mathrm{LC}_{50}$ and $\mathrm{LC}_{90}$ were found to be $251.14,839.89$ and $8326.2 \mathrm{ppm}$ after 24 hours of application, respectively on the cotton mealybug $P$. solenopsis.
\end{abstract}

Key words: Moringa plant, $M$. oleifera, Biopesticide.

\section{INTRODUCTION}

Under the shadow of Moringa genus, there are 13 species of trees and shrubs were sheltered Moringa oleifera Lam. is the most abundant. It distributed in numerous countries. Its tree is rapidly grow. It ranges in height from 5 to $10 \mathrm{~m}$ which has a whitish bark with tuberous roots. Its leaves are alternate, twice- or thrice-pinnate leaves and spirally arranged. Its wood is softly spongy. It has a short trunk and slender branches. The flowers pleasantly fragrant and $2.5 \mathrm{~cm}$ wide are white or creamcolored. The fruits (pod-like capsules) borne singly or in pairs. The seeds are spherical, 7 to $8 \mathrm{~mm}$ in diameter, with 4 papery wings and are yellow grey.

The plant has a high value. It has a wide range of medicinal and nutritional values. The leaves and fruits are edible and found to be a part of traditional diets in many countries Siddhuraju and Becker, (2003) and Anhwange et al. (2004). The leaves of
M. oleifera are a good source of calcium, Ascorbic-acid (vitamin C) in addition to carbohydrate and protein (Ogbe and Affiku, 2012). The seeds also contain a large amount of fatty acid like Arachidic, Behenic, Oleic and Palmitic acid that use in industrial sector such as production of detergent, hair conditioner, insects pheromones and in cosmetics Abdulkarim et al. (2005).

This economics crop is submitting to hard invasion by numerous pests, some have piercing mouth parts. The two-spotted spider mite Tetrancus urticae (Koch) has piercing mouth parts. This pest is one of the most common plant pests. The red mites causes great damage to the major crops Rodriguez et al. (1970), Sances et al., (1981) and Shanks and Doss (1989), showed that the feeding on leaf mesophyll by the mites can substantially reduce photosynthesis and plant vigor. WuKongming (1989) confirmed that cotton photosynthesis process was reduced owing

\footnotetext{
* Corresponding author: Tel.: +201222494484

E-mail address: ghadaelmasry2017@gmail.com
} 
to the decreased chlorophyll, likewise, the contents of most of 17 amino acids, especially the glutamic acid, histidine, and turosine were decreased obviously.

Cotton mealybug (Phenacoccus solenopsis Tinsley) is a soft-bodied insect that sucks the cell sap (Aijun et al., 2004). It has been reported as a serious pest in Egypt. This pest is suspected as a vector of plant diseases (Culik and Gullan, 2005). It has been recorded on 154 plant species including field crops, vegetables, ornamentals, weeds, bushes and trees (Arif et al., 2009).

The condensate use of pesticide to control the two formed pests cause great problem. Resistance and pollution are two serious problems. So, there are necessity to get new and saved effective compounds against the mites and mealy bugs.

The aim of this work is to extract a natural compound that may be present in M. oleifera to control certain sucking pests.

\section{MATERIALS AND METHODS}

\section{Extraction and Isolation}

Fresh seeds of Moringa oleifera Lam. plants were collected from the farm of Ismailia Agriculture Research station (IARC), Egypt on October 2015. Samples were transferred to the laboratory of plant protection at IARS. Seeds were left to dry under the laboratory condition for two weeks. Dry seeds were ground by the aid of grinding mill in moulinex blender (France), then sieved (mesh size of $0.841 \mathrm{~mm}$ and $0.42 \mathrm{~mm}$ ). Methylene chloride $\mathrm{CH}_{2} \mathrm{Cl}_{2}$ was added to $50 \mathrm{~g}$ of seed powder and stored in glass bottles at lab temperature for 3 days. The mixture was filtered with whattman No.1 filter paper. The filtrate was concentrated in vacuum to afford a crude extract. A glass column $(51 \times 5.1 \mathrm{~cm})$ was packed with each of silica gel and the crude extract at a ratio of 1:25 (W/W), respectively (Anwar and Rashid, 2007).

\section{Identification}

The obtained fraction were submitted to identify using FTIR, ${ }^{1}$ Hydrogen and ${ }^{13}$ Carbon Nuclear magnetic resonance spectroscopy

\section{Laboratory Experiment}

\section{Maintenance of insect's colonies}

\section{Mites colony}

For maintaining a colony of spider mite Tetranychus urticae (Koch) in the laboratory, the method described by Nasser (1974) was followed. The colony was kept away from any insecticides contamination for 9 months.

\section{Mealybug colony}

Potatoes tubers were washed thoroughly in distilled water; air dried and put on moist gunny bag. Water was sprinkled daily to keep the bag moistened to encourage sprouting. After 28-30 days potatoes produced sprouts of $5-7 \mathrm{~cm}$, a suitable plant stage for mealybug, Phenacoccus solenopsis Tinsley rearing. The mealybug was reared according to the procedures of Vennila et al. (2010).

The sprouted potatoes were placed in plastic cages $(70 \mathrm{~cm}$ length $\times 40 \mathrm{~cm}$ width $\times 40 \mathrm{~cm}$ height) and for aeration $0.02 \mathrm{~mm}$ mesh was used on both sides of the cage. Nymphs and adults of mealybug were collected from cotton fields. These two stages of mealybug were maintained and mass multiplied on the sprouted potatoes. Four plastic pots (diameter $25 \mathrm{~cm}$ ) were full with proper soil. Each pot was planted with four cotton seeds. The pots were kept in cages $(60 \times 60 \times 120 \mathrm{~cm})$. Four cages were used.

From these colonies, gravid females of mealybug were transferred to the spores cotton plants in the cages for conditioning (3 to 4 days) adapt to the cotton plant and then produce the offspring/ovisacs on cotton plant. Colonies of mealy bugs on cotton plants were used in experiments. 


\section{Toxicity test}

Leaf disc technique was used to determine the toxicity of the obtained extract fraction from moringa seeds against the adult stage of mites and mealy bugs. In this respect, small circular leaf discs (1 inch in diameter) punched from cotton leaves were dipped in aqueous diluation of the tested compound for five seconds. The discs were left to dry up for 15 minutes, and then placed in petri-dishes lined with water saturated cotton wool.

The discs were surrounded by a light repellent tangle foot. Twenty adult females were transferred to/on the lower surface of each disc. Each petri-dish contained 4 discs (each disc represented a replicate). Six concentrations of the tested compounds were used to give the mortality between 20$80 \%$ against the adult females. Mortalities were recorded after 24 hours of treatment. The criterion for mortality was the failure of mites to respond positively by leg movement following light prodding with a fine brush.

The percentage mortality in all treatments was corrected using Abbott's formula (1925), where the toxicity lines were statistically analyzed according to the method described by Finney (1971). The same procedures were followed with the mealybugs.

\section{RESULTS AND DISCUSSION}

\section{Extraction and isolation}

Six unknown compounds were isolated from moringa seeds. The toxicity of these compounds was evaluated against of each of the two spotted spider mites and mealy bugs, only one compound was effective. This compound was submitted to identify using Fourier Transform Infrared spectroscopy, (FTIR) and Carbon ${ }^{13}$ and Hydrogen ${ }^{1}$ Nuclear magnetic resonance spectroscopy

\section{Fourier Transform Infrared spectroscopy, (FTIR)}

Fourier Transform Infrared spectroscopy, (FTIR) analyses as shown in Fig. (1) showed five peaks. The first peak lies between $\sim 3200-3400 \mathrm{~cm}^{-1}$ represent the $(\mathrm{O}-$ $\mathrm{H})$ free groups. The $2^{\text {nd }}$ peak at $\sim 2050 \mathrm{~cm}^{-1}$ represent the presence of isothiocyanates. Two peaks lies at $\sim 1600$ and $\sim 1500-1430$ $\mathrm{cm}^{-1}$ represent the presence of aromatic ring. The $5^{\text {th }}$ peak was between $1000-1220$ $\mathrm{cm}^{-1}$ represents the (-C-O-C-) stretching of etheric bond.

\section{${ }^{1}$ Hydrogen Nuclear magnetic resonance spectroscopy, $\left({ }^{1} \mathrm{H}\right.$ NMRO)}

The ${ }^{1} \mathrm{H}$ NMR spectrum of the isolated effective compound in DMSO is shown in Fig. (2). ${ }^{1}$ H-NMR spectra are composed of peaks which indicate the presence benzyl isothiocyanates group peak shift at $~ 7-7.5$ ppm and the peak at $\sim 5 \mathrm{ppm}$ which indicate the presence of rhamnosyl group.

${ }^{13}$ Carbon Nuclear magnetic resonance spectroscopy, $\left({ }^{13} \mathrm{C}\right.$ NMRO)

The ${ }^{13} \mathrm{C}$ NMR spectrum of the isolated effective compound in DMSO is shown in figures (3). ${ }^{13} \mathrm{C}$-NMR spectra are composed of peaks which indicate the presence of benzyl isothiocyanates group (5 carbon) which shift between $\sim 125$ and $135 \mathrm{ppm}$. Peak shift between 17 to $95 \mathrm{ppm}$ is for Rhamnosyloxy.

The figure indicates that the obtained substance is Rhamnosyloxy-benzyl isothiocyanate.

Toxicity of Rhamnosyloxy-benzyl isothiocyanate on the adult females of the two spotted spider mite Tetrancus urticae (Koch) and mealybug Phenacoccus solenopsis Tinsley

The efficiency effect of the compound was tested against the two spotted spider mite after 1, 3 and 7 days.

Results in Table 1 show that respective values of $\mathrm{LC}_{25}, \mathrm{LC}_{50}$ and $\mathrm{LC}_{90}$ were 150 , 388 and $2370 \mathrm{ppm}$ after 24 hours of application.

The efficiency effect of the compound was also estimated against the females of mealybug. Results in Table (2) show that respective values of $\mathrm{LC}_{25}, \mathrm{LC}_{50}$ and $\mathrm{LC}_{90}$ were $251.14,836.89$ and 8326.29 ppm after 24 hours of application. 


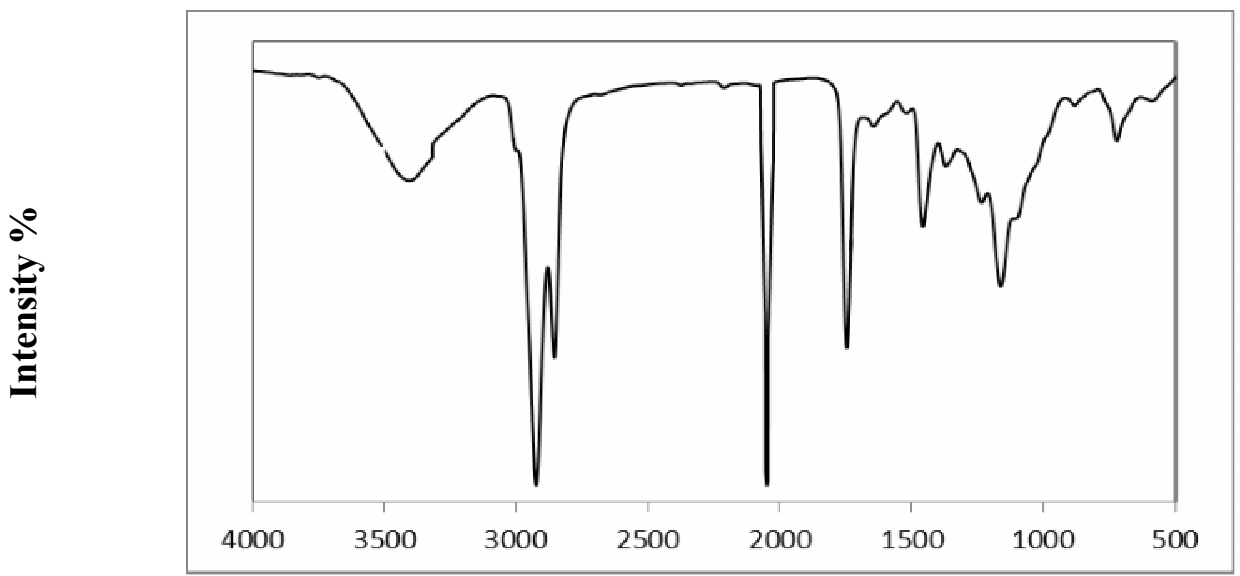

Wave length $\left(\mathrm{cm}^{-1}\right)$

Fig. (1): Infrared spectrum of the isolated compound.

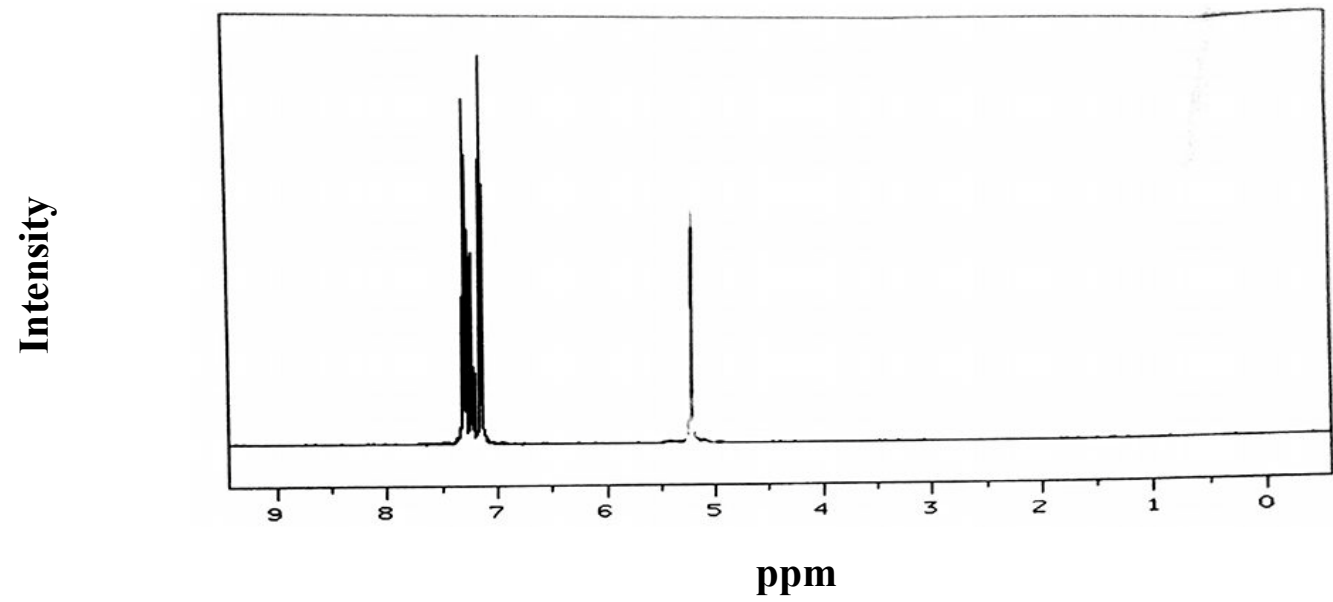

Fig. (2): ${ }^{1} \mathrm{H}$ NMR spectrum of the isolated compound.

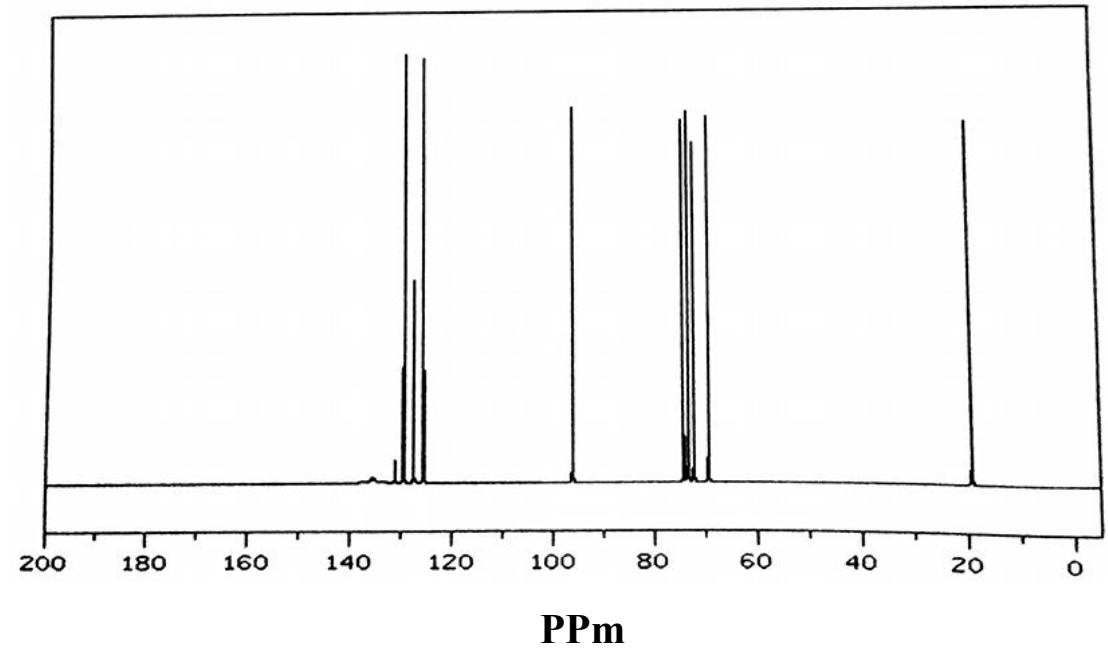

Fig. (3): ${ }^{13} \mathrm{C}$ NMR spectrum of the isolated compound. 


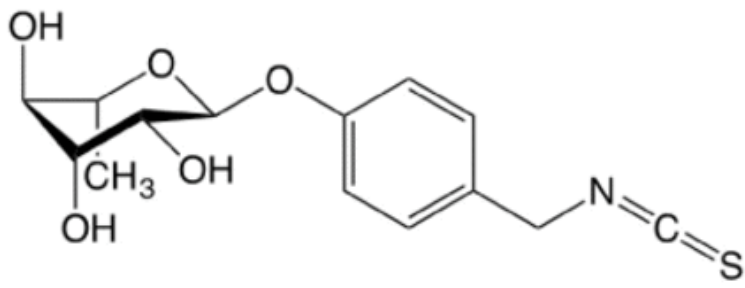

Fig. (4): Structure of Rhamnosyloxy-benzyl isothiocyanate.

Table (1): Toxicity of Rhamnosyloxy-benzyl isothiocyanate on the adult females of the two spotted spider mite Tetrancus urticae (Koch)

\begin{tabular}{ccccc}
\hline Time (day) & \multicolumn{3}{c}{ LC (ppm) } & Slop \\
\cline { 2 - 4 } & $\mathbf{2 5}$ & $\mathbf{5 0}$ & $\mathbf{9 0}$ & \\
\hline 1 & 150 & 388 & 2370 & 1.6 \\
\hline
\end{tabular}

Table (2): Toxicity of Rhamnosyloxy-benzyl isothiocyanate on the adult females of mealybug Phenacoccus solenopsis Tinsley.

\begin{tabular}{ccccc}
\hline Time (day) & \multicolumn{3}{c}{ LC(ppm) } & Slop \\
\cline { 2 - 4 } & $\mathbf{2 5}$ & $\mathbf{5 0}$ & $\mathbf{9 0}$ & \\
\hline 1 & 251.14 & 839.89 & 8326.2 & 1.286 \\
\hline
\end{tabular}

Discussing the forgoing result, it could be seen that Rhamnosyloxy-benzyl isothiocyanate had each toxic effect against each of the adult female of mites and on mealybug.

It is clear that Rhamnosyloxy-benzyl isothiocyanatecan play an effective role against both mites and mealybug.

\section{Acknowledgments}

The authors are grateful thanks for the support of Prof. Dr. Abdullah El-Adawy, head researcher of acarology, Plant Protection Institute, Agriculture Research Center for his valuable comments for sharing me in all steps of the study and for his valuable advices, offering all facilities which contributed much in the progress of this work.

\section{REFERENCES}

Abbott, W.S. (1925). A method of computing effectiveness of an insecticide. J. Entomol., (18): 265-267.

Abdulkarim, S.M.; Long, K.; Lai, O.M.; Muhammad, S.K.S. and Ghazalia, H.M. (2005). Some physico-chemical properties of Moringa oleifera seed oil extracted using solvent and aqueous enzymatic methods. J. Food Chem., 93 (2): $253-263$.

Aijun, Z.; Divina, A.; Shyam, S.; Miguel, S.S.; Rosa, A.F.; James, E.O.; Jerome, A.K.; Jeffrey, R.A.; Dale, E.M. and Stephen, L.L. (2004). Sex pheromone of the pink hibiscus mealybug, Maconellicoccus hirsutus, contains an unusual cyclobutanoidmonopterpene. 
The Nat. Acad. Sci. USA, 101: 96019606.

Anhwange, B.A.; Ajibola, V.O. and Oniye, S.J. (2004). Chemical studies of the seeds of Moringa oleifera Lam. and Detarium microcarpum (Guill and Sperr). J. Biol. Sci., 4: 711-715.

Anwar F. and Rashid, U. (2007). Physicochemical characteristics of Moringa oleifera seeds and seed oil from a wild provenance of Pakistain. Pak. J. Bot., 39: 1443-1453.

Arif, M.I.; Rafiq, M. and Ghaffar, A. (2009). Host plants of cotton mealybug Phenacoccus solenopsis anew menace to cotton agroecosystem of Punjab, Pakistan. Int. J. Agric. Biol., 11: 163-167.

Culik, M.P. and Gullan, P.J. (2005). A new pest of tomato and other records of mealybugs (Hemiptera: Pseudococcidae) from Espírito Santo, Brazil. J. Zootaxa., 964: 1-8.

Finney, D.J. (1971). Probit Analysis $\left(3^{\text {rd }}\right.$ Ed.) A Statistical Treatment of the Sigmoid Response Curve. (Cambridge University press).

Nasser, M.E. (1974). Resistance to organophosphorus insecticides. M.Sc. Thesis Fac. Agric., Ain Shams Univ., Egypt.

Ogbe, A.O. and Affiku, J.P. (2012). Proximate study, mineral and antinutrient composition of moringaoleifera leaves harvested from lafia, nigeria: potential benefits in poultry nutrition and health. J. Microbiol., Biotechnol. and Food Sci., 1 (3) : 296-308.

Rodriguez, J.G.; Chaplin, C.E.; Stoltz, L.P. and Lasheen, A.M. (1970). Studies on resistance of strawberries to mites. 1Effect on plant nitrogen. J. Econ. Entomol., 63: 1855-1858.

Sances, F.V.; Wyman, J.A.; Ting, I.P.; VanSteenwyk, R.A. and Oatman, E.R. (1981). Spider mite interaction with photosynthesis transpiration and productivity of strawberry Environ., J. Entomol., 10:442-448.

Shanks, C.H. and Doss, R.P. (1989). Population fluctuations of two spotted spider mite. J. Environ. Entomol., 18: 641-645.

Siddhuraju, P. and Becker, K. (2003). Antioxidant properties of various solvent extracts of total phenolic constituents from three different agro-climatic origins of drumstick tree Moringa oleifera Lam., J. Agric. Food Chem., 15: 2144-2155.

Vennila, S.; Deshmukh, A.J.; Pinjarkar, D.; Agarwal, M.; Ramamurthy, V.V.; Joshi, S.; Kranthi, K.R. and Bambawalei, O.M. (2010). Biology of the mealybug, Phenacoccus solenopsis Tinsley on cotton in the laboratory. J. Insect Sci., 10 (115): 1-9.

Wu-Kongming (1989). The effect of carmine spider mite [Tetranychus cinnabarinus] infestation on the physiological activities of cotton .ActaPhytophylacica- Sinica (China), 16 (2): 99-106. 


$$
\begin{aligned}
& \text { الملخص العربي } \\
& \text { نبـات المورنجــا"Moringa oleifera" كمصـــــ للمبيدات الحيــويـة } \\
& \text { غاده نبيل المصري، فاطمه محمد صالح، سناء عبدالبديع محمد عبدالمجيا } \\
& \text { معهد بحوث وقاية النباتات، مركز البحوث الزراعية، الجيزة، مصر. }
\end{aligned}
$$

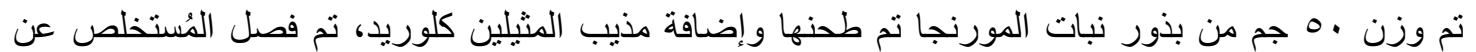

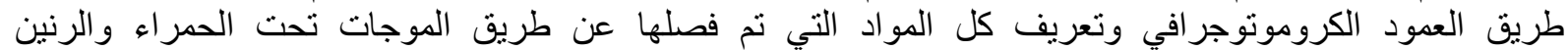

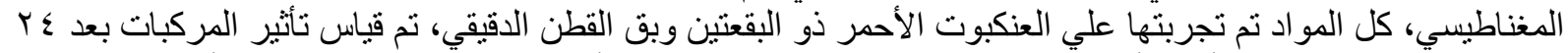

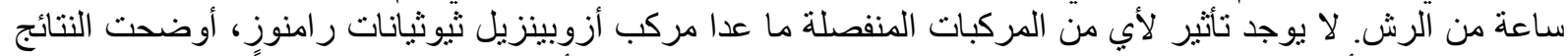

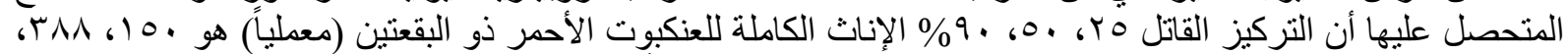
• •

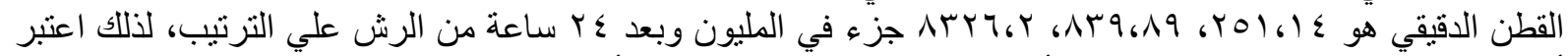

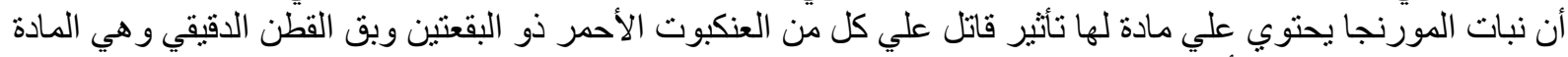

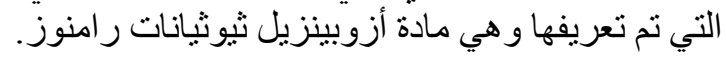

الكلمات الإسترشادية: نبات المورنجا Moringa oleifera، المبيدات الحيوية، العنكبوت الأحمر ذو القبعتين، وبق القطن الدقيقي.

أستاذ الحشرات الاقتصادية، كلية العلوم الزر اعبة البيئية، جامعة العريش، مصر.

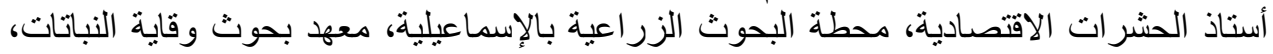

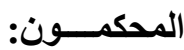

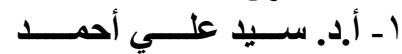
r أ. أ.د. عبدالله محمد المرسي أحيد 
El-Masry, et al. 